\title{
HADITS MISOGINIS PERSPEKTIF GENDER DAN FEMINISME
}

\author{
Ade Marhamah \\ Fakultas Ushuluddin, Adab dan Humaniora IAIN Salatiga, Jawa Tengah, Indonesia. \\ Marhamatululya@gmail.com
}

\begin{abstract}
Abstrak:
Maraknya berita tentang kekerasan pada perempuan di media sosial menjadi bukti bahwa kekerasan pada perempuan tidak pernah usai. Indonesia dengan struktur sosial budaya patriarki yang masih melekat kuat pada masyarakat menghasilkan stigma perempuan sebagai makhluk nomor dua dari laki-laki, dianggap lemah dan harus menuruti apa yang menjadi keinginan laki-laki itu sendiri. Fakta-fakta yang muncul dari lingkungan masyarakat tersebut memunculkan kekhawatiran, akan terjadinya kekerasan fisik atau verbal khususnya kepada perempuan. Bahkan tidak jarang kekerasan tersebut disertai atas nama ayat-ayat suci dan hadits- hadits nabi sebagai legitimasi atas perbuatan pelaku. Padahal jika dilihat dari al-Quran itu sendiri, al-Quran mengandung ayat-ayat yang memuliakan perempuan. Jika haditshadits tersebut berasal dari Nabi, tentunya Nabi tidak mungkin mengajarkan kekerasan pada perempuan. Mengingat nabi digambarkan dalam al-Quran al-Karim sebagai uswatun hasanah. Tidak hanya itu, menurut sejarah (sirah nabawiyyah), Nabi juga senantiasa memuliakan dan menghormati perempuan. Tujuan tulisan ini adalah untuk menganalisis bagaimana kemunculan hadits-hadits yang menunjukkan ketidakadilan pada perempuan melalui pendekatan feminisme dan gender dengan sejarah yang mendampinginya. Hasilnya menunjukkan bahwa terdapat tiga formulasi pembacaan kaum feminis terhadap hadits misogini. Pertama, ada pembawa hadits pada salah satu atau lebih level sanad yang menggunakan hadits secara politis untuk mendukung tegaknya tradisi patriarkal. Kedua, metodologi kritik hadits yang lebih berorientasi untuk mengungkap keshahihan sanad pada matan serta berpihak pada truth claim yang berakibat adanya suatu generasi tertentu yang dipandang tanpa cacat dalam meriwayatkan hadits. Ketiga, pemahaman matan hadits yang dilakukan secara doktrinal-normatif tanpa melihat proses hermeneutis yang terjadi seputar pembentukan teks (penyingkapan pesan moral teks). Implikasi dari tulisan ini adalah perlunya kesadaran para peneliti hadits dalam memahami dan menerima sebuah hadits secara kompleks, jangan hanya terfokus pada kebenaran sanad hadits, namun perlu memperjelas kesesuaian teks/matan hadits dengan konteks setiap zaman.
\end{abstract}

Kata Kunci : Hadits, Misoginis, Keadilan

\begin{abstract}
The rise of news about violence against women on social media is proof that violence against women never ends. Indonesia with a patriarchal socio-cultural structure that is still firmly attached to society produces the stigma of women as the number two creature of men is considered weak and must obey what men desire themselves. The facts that arise from the community environment raises concerns, there will be physical or verbal violence, especially to women. Not infrequently the
\end{abstract}




\section{AT-TIBYAN}

Journal Of Qur'an and Hadis Studies

Vol. 2 No. 2 (Desember 2019)

violence is accompanied in the name of the holy verses and hadiths of the prophet as legitimacy for the perpetrators. Yet when viewed from the Koran itself, the Koran contains verses that glorify women. If the hadiths come from the Prophet, of course, the Prophet may not teach violence to women. Remembering the prophet is described in the Koran al-Karim as uswatun hasanah. Not only that, according to history (Sirah Nabawiyyah), the Prophet also always glorified and respected women. The purpose of this paper is to analyze how the emergence of hadiths that show injustice to women through feminism and gender approaches with a history that accompanies it. The results show that there are three formulations of feminist readings on the misogyny hadith. First, there are hadith carriers at one or more levels of sanad that use hadith politically to support the establishment of patriarchal traditions. Secondly, the methodology of hadith criticism is more oriented to reveal the validity of sanad to death and side with truth claims that result in a certain generation that is seen as flawless in narrating the hadith. Third, understanding the meaning of hadith which is done doctrinally-normatively without seeing the hermeneutical process that occurs around the formation of texts (the disclosure of the moral message of the text). The implication of this paper is the need for the awareness of hadith researchers in understanding and accepting a hadith in a complex manner, not only focusing on the truth of the hadith sanad, but it is necessary to clarify the suitability of the text / Matan hadith with the context of each age.

Keywords: Hadith, Misogynist, Justice

\section{PENDAHULUAN}

Perkembangan ilmu pengetahuan semakin maju, begitu pula teknologi sudah sedemikian pesatnya mengalami perubahan-perubahan setiap detiknya. Adalah internet dan dunia maya yang semakin menguasai berbagai lini. Beragam informasi tersaji baik itu asli maupun palsu. Salah satu berita yang tak pernah usai diperbincangkan adalah informasi kekerasan atau pelecehan pada perempuan. Terlepas yang dianggap salah adalah laki-laki atau perempuan, perempuan selalu menjadi objek kekerasan tersebut. Bahkan di antara pelaku kekerasan tersebut menggunakan ayat-ayat suci atau hadits sebagai legitimasi atas perbuatannya.(Lufaefi, 2017, hlm. 2)

Ketimpangan sosial atau ketidak-adilan tersebut menggugah kesadaran kaum feminis untuk mempertanyakan sebenarnya apa yang terjadi dalam hadits yang bernada misoginis itu. Mengingat Nabi Muhammad saw dalam sejarah dikatakan tidak pernah melakukan hal-hal yang merugikan perempuan. Nampaknya hadits-hadits tersebut harus dipertanyakan dan dikaji kembali dengan pendekatan feminisme, gender dan sejarah yang mengitarinya. Agar keadilan dan kesetaraan antara laki-laki dan perempuan bisa diwujudkan. 
Vol. 2 No. 2 (Desember 2019)

\section{PEMBAHASAN}

Konsep mendasar yang ditawarkan oleh feminisme untuk menganalisis masyarakat adalah gender. Secara etimologis kata 'gender' berasal dari bahasa Inggris yang berarti 'jenis kelamin' Dalam Webster's New World Dictionary, Edisi 1984 'gender' diartikan sebagai 'perbedaan yang tampak antara laki-laki dan perempuan dilihat dari segi nilai dan tingkah laku'.(Umar, 1999, hlm. 33)

Secara terminologis, gender bisa didefinisikan sebagai harapanharapan budaya terhadap laki-laki dan perempuan. Gender dipandang sebagai suatu konsep kultural yang dipakai untuk membedakan peran, perilaku, mentalis, dan karakteristik emosional antara laki-laki dan perempuan yang berkembang dalam masyarakat. Difahami bahwa gender merupakan suatu sifat yang dijadikan dasar untuk mengidentifikasi perbedaan antara laki-laki dan perempuan dilihat dari segi kondisi social dan budaya, nilai dan perilaku, mentalitas, dan emosi, serta factor-faktor nonbiologis lainnya.(Rokhmansyah, 2016, hlm. 1)

Gender secara umum digunakan untuk mengidentifikasi perbedaan laki-laki dan perempuan dari segi sosial budaya, maka sex secara umum digunakan untuk mengidentifikasi perbedaan laki-laki dan perempuan dari segi anatomi biologi. Istilah sex (dalam kamus bahasa Indonesia juga berarti "jenis kelamin") lebih banyak berkonsentrasi kepada aspek biologi seseorang, meliputi perbedaan komposisi kimia dan hormon dalam tubuh, anatomi fisik, reproduksi, dan karakteristik biologis lainnya. Sedangkan gender lebih banyak berkonsentrasi kepada aspek sosial, budaya, psikologis, dan aspek-aspek non biologis lainnya. Studi gender lebih menekankan pada aspek maskulinitas (masculinity) atau feminitas (femininity) seseorang. Berbeda dengan studi sex yang lebih menekankan kepada aspek anatomi biologi dan komposisi kimia dalam tubuh laki-laki (maleness) dan perempuan (femaleness).(Ara \& Ananda, 2004, hlm. 2) Proses pertumbuhan anak (child) menjadi seorang laki-laki (being a man) atau menjadi seorang perempuan (being a woman), lebih banyak digunakan istilah gender dari pada istilah sex. Istilah sex umumnya digunakan untuk merujuk kepada persoalan reproduksi dan aktivitas seksual (love-making activities), selebihnya digunakan istilah gender.(Bhasin \& Nighat, 1994, hlm. 12)

Begitupun menurut Anne Oakley, Pemakaian kata gender dalam feminisme mula pertama dicetuskan olehnya. Dia memulainya dengan mengajak warga dunia untuk memahami bahwa ada dua istilah yang serupa, tetapi tidak sama, yaitu sex dan gender. Selama ini masyarakat menganggap kedua istilah itu sama saja, yaitu sebagai sesuatu yang harus diterima secara 
Vol. 2 No. 2 (Desember 2019)

taken for granted (mengganggap sudah semestinya begitu). Padahal berbicara tentang perubahan sosial (proses kontruksi, dekonstruksi, dan rekonstruksi) membutuhkan pemahaman yang baik tentang mana wilayah nature dan mana wilayah curture. Kedua istilah tersebut merupakan derivasi dari bahasa Inggris yang sekarang telah banyak dipakai oleh masyarakat Indonesia.(Muslikhati, 2001, hlm. 19)

Adanya ketimpangan dalam gender membangkitkan kaum feminis untuk menuntut hak mereka yang ditutupi sekian lamanya. Feminism sebagai sebuah ide (sebuah kesadaran) yang kemudian melahirkan gerakan, pada intinya membicarakan wilayah culture. Dan pemahaman yang baik tentang wilayah culture memungkinkan mereka punya peluang untuk berbicara tentang perubahan. Pembahasan tentang bagaimana feminisme lahir dimulai dengan pemaparan tentang bagaimana masyarakat memandang tentang peempuan, higga munculnya kesadaran diri dari sekelompok orang (yang berperan sebagai agent of change) terhadap adanya ketidakadilan (tidak egaliter) terhadap perempuan di dalam cara pandang masyarakat tersebut. Kedudukan perempuan dalam pandangan umat-umat sebelum Islam sangat rendah dan hina.(Muslikhati, 2001, hlm. 22)

Adanya perlakuan yang tidak manusiawi terhadap perempuan atau maraknya kebencian terhadap wanita memunculkan istilah baru, misoginis. Istilah misoginis berasal dari kata dalam Bahasa Inggris Misogyny yang berarti kebencian terhadap perempuan. Sedangkan dalam kamus ilmiah popular terdapat tiga ungkapan yaitu (1) Misogin yang berarti benci akan perempuan/ membenci perempuan (2) Misogini berarti perasaan benci akan perempuan, dan (3) Misoginis yang berarti laki-laki yang benci kepada perempuan. Namun secara terminologi juga dipakai untuk mengartikan doktrin sebuah aliran pemikiran yang secara dhahir memojokkan dan merendahkan derajat perempuan.(Ainiyah, 2015, hlm. 138-139)

Istilah misogini berawal dari adanya mitos tentang penciptaan wanita dan keluarnya Adam dari surga ke bumi. Menjadi sebab munculnya banyak perlakuan kasar dan negatif terhadap wanita. cerita tersebut menggambarkan bahwa wanita diciptakan menjadi makhluk yang bertujuan melengkapi hasrat Adam, dan sebab jatuhnya Adam ke bumi karena godaan Hawa. Cerita ini melahirkan faham misoginis (pembencian wanita oleh pria). Faham yang berasal dari ajaran Yahudi-Kristen ini berpengaruh cukup luas di dalam dunia Arab melalui berbagai media, bahkan dalam kita tafsir dan fikih pun tak terlewatkan.(Rufikasari, 2014, hlm. 25)

Sebagian mitos sebagai akar kebencian terhadap kaum wanita juga bisa dilihat dari penjelasan Hyde. Menurut Hyde, dalam diri kaum wanita 
dilekatkan mitos-mitos yang kurang menguntungkan bagi mereka antara lain mitos mengenai kejahatan feminim (feminie evil) yang berasal dari tradisi Judeo-Kristen mengenai kejatuhan manusia dari surga karena kesalahan Eva membujuk Adam untuk memakan buah dari pohon pengetahuan. Perbuatan ini dianggap sebagai akar dari dosa asal seluruh umat manusia yang disebabkan oleh perbuatan Eva (wanita). Pandora dikenal sebagai mitos mengenai manusia wanita pertama di dunia, yang membuka kotak terlarang sehingga menyebarlah benih - benih kejahatan di seluruh dunia ini, mitos Pandora ini berasal dari Yunani. Kemudian ada lagi di Cina dikenal dengan dua kekuatan yaitu Yin dan Yang. Di antara keduanya ada yang berhubungan dengan aspek feminim dan ada juga yang berhubungan dengan aspek maskulin. Yin yang feminim berkaitan dengan kegelapan, kejahatan, sisi dari alam. Sedangkan Yang yang maskulin berkaitan dengan sisi kebalikan Yin tersebut.(Rufikasari, 2014, hlm. 25)

Sejarah munculnya misogynist banyak merasuk pada teolog-teolog agama. Seperti pada kehidupan religius Judo-Kristiani. Pendapat tokoh-tokoh seperti Tertulliaus, Agustinus, Thomas Aquinas, Martin Luther, John Knox ataupun Paus Pius XII. Para tokoh-tokoh tersebut telah menunjukkan bagaimana kebencian terhadap wanita itu tidak dapat dipungkiri bisa saja muncul dari kalangan religius.(Rufikasari, 2014, hlm. 28)

Adapun Persoalan sejarah kedudukan perempuan ini dikupas panjang lebar oleh Nawal el Saadawi dalam salah satu bukunya The Hidden Face of Eve yang sudah diterjemahkan ke dalam bahasa Indonesia dengan judul Perempuan dalam Budaya Patriarki. El Saadawi mengemukakan dalam buku tersebut bahwa konsep tentang agama berkembang di dalam pikiran manusia jauh sebelum agama-agama monoteis muncul. Orang-orang Mesir Kuno, misalnya, telah memiliki agama sendiri sebelum agama Yahudi masuk ke dalam lingkungan mereka. Menurut keyakinan agama Mesir Kuno dewadewa perempuan berdampingan dengan dewa-dewa laki-laki bersama-sama berkuasa atas nasib kehidupan mereka. Perempuan menempati pada tempat yang tinggi seperti diduduki dewa-dewa itu adalah cerminan bagaimana kedudukan perempuan-perempuan tersebut dalam masyarakat sebelum adanya sistem yang dicirikan oleh keluarga patriarkhat, kepemilikan tanah, dan pembagian masyarakat menjadi kelas-kelas sosial. Dengan lahirnya sistem-sistem ini, kedudukan perempuan perlahan-lahan jatuh merosot dan berlanjut ke masa-masa sesudahnya.(el Saadawi, 2001, hlm. 183-185)

Perkembangan selanjutnya secara paralel dibarengi dengan kemerosotan status dan kedudukan perempuan diawali dari kelas penguasa pemilik tanah hingga akhirnya keseluruhan masyarakat 
Vol. 2 No. 2 (Desember 2019)

berlangsung di bawah dominasi ekonomi, sosial, dan keagamaan dari kaum laki-laki. Laki-laki memonopoli agama untuk tujuan-tujuannya sendiri serta untuk para dewa laki-laki pula, sementara perempuan terpuruk ke jenjang kedudukan keagamaan yang paling rendah. Proses ini berlangsung paralel dengan perkembangan kepemilikan pribadi. Struktur-struktur lama diganti dengan sistem-sistem yang didasarkan pada eksploitasi dan perempuan dibuang ke dasar terbawah struktur masyarakat. Hingga perkembangan agama-agama monoteis, struktur tersebut tidak berubah. Para penafsir keagamaan semakin memperkokoh struktur tersebut dengan mengangkat ayat-ayat suci sebagai legitimasi atas struktur tersebut. Budaya Arab yang patriarkhi banyak mempengaruhi para ulama Muslim dalam menafsirkan konsep-konsep agama Islam. Sebagaimana diakui, bahwa fikih Islam lahir sebagai formulasi hukum yang mencakup berbagai aspek kehidupan masyarakat tertentu yang didasarkan pada alQuran dan Sunnah. Dapat juga dikatakan, bahwa fikih Islam merupakan perpaduan antara ajaran inti Islam dengan budaya lokal (tradisi).(el Saadawi, 2001, hlm. 9)

Dari sudut pandang feminisme Islam, patriarkhi dianggap sebagai asal-usul dari seluruh kecenderungan misoginis (kebencian terhadap perempuan) yang mendasari teks keagamaan yang bias kepentingan lakilaki (bias gender). Di sinilah para feminis Muslim sekarang ini, seperti Fatima Mernissi seorang feminis Islam kelahiran Maroko pada tahun 1940. Mernissi memiliki pemikiran bahwa ada tiga persoalan yang melanggengkan terjadinya penanggung jawab tegaknya Islam di rumah (domistifikasi peran perempuan). Akibatnya pendidikan perempuan sebatas bekal untuk pembinaan keluarga. Kedua, dominasi laki-laki terhadap penafsiran teks-teks keagamaan mengakibatkan hasil penafsiran banyak berpihak kepada kepentingan laki-laki. Banyak sekali hadits-hadits yang ditafsirkan kaum lakilaki memberi legitimasi atas kelanggengan peran laki-laki di ruang sosial, politik dan keilmuan. Berdasarkan penafsiran itu pula, kaum perempuan dikucilkan dari pentas sosial, politik dan pendidikan. Ketiga, legitimasi teologis yang berpihak kepada laki-laki. Dengan demikian laki-laki memiliki peluang yang lebih besar dibandingkan peempuan dalam memegang otoritas sosial dan politik.(Kadarusman, 2005, hlm. 70)

Tokoh kedua yaitu Riffat Hassan. Riffat Hasan adalah seorang feminis muslimah yang lahir di Lahore, Pakistan. Meski demikian tahun kelahirannya tidak diketahui secara jelas. Tetapi Riffat Hasan dilahirkan dari keluarga terhormat, ayahnya adalah seorang tokoh masyarakat yang memiliki darah sayyid. Masyarakat setempat menghormati keluarga Riffat Hasan karena 
Vol. 2 No. 2 (Desember 2019)

kedua orangtuanya dari keluarga trkemuka. Meski demikian kedua orang tua Riffat Hasan berselisih pandangan dalam memahami ajaran agama. Perbedaan keduanya terletak pada ideology yang mempengaruhi paradigm berfikir yaitu, ayah Riffat dianggap sebagai penganut paham tradisionalis yang teguh memegang ajaran agama dengan gaya patriarki. Tetapi ibunya dianggap sebagai pejuang feminism "radikal" yang keras menolak praktekpraktek patriarki yang berkembang di masyarakat.(Muhtador, 2017, hlm. 261)

Secara histori, budaya patriarki yang berkembang di Pakistan pada waktu itu lebih mencerminkan male diminatio, corak tersebut menjadi salah satu factor yang menginspirasi Riffat Hasan dalam memperjuangkan nasib perempuan. Perjuangan Riffat Hasan dimulai dengan Reformasi bagi kaum perempuan yang pada akhirnya menuntunnya menjadi feminis yang aktif demi tegaknya nilai keadilan di masyarakat tanpa membedakan jenis kelamin laki-laki ataupun perempuan.(Muhtador, 2017, hlm. 262)

Ketiga, Nawal el Sadawi merupakan seorang feminis dari mesir yang membongkar budaya patriarki di Mesir, melalui karya novelnya yang kontroversial. Feminis menurutnya adalah universal, berjuang dengan segala yang dimiliki perempuan, termasuk kesetaraan gender yang didengungkan oleh Barat. Disamping itu juga mengkritik pemerintah tentang kebijakan di bidang ekonomi. Karena hal ini, sangat merugikan kaum perempuan pada masanya.(Kulsum, 2017, hlm. 104)

Yang ke empat, Asghar Ali Engineer, beliau lahir di Salumbar dekat Udaipur pada tanggal 10 Maret 1939 dari keluarga ulama terpandang. Adapun bingkai utama pemikiran Asghar adalah teologi pembebasan. Teori pembebasan Asghar berlandaskan pada Al-Quran dan sejarah Nabi Muhammad SAW. Mungkin inilah yang membedakan dengan teologi pembebasan gaya Amerika Latin yang hanya bersandar pada kitab Injil semata. Teologi pembebasan yang dimaksud Asghar bersifat konkret, kontekstual, dan praksis. Ia berada pada realitas kekinian dan bertolak dari kondisi social yang ada. Ia juga merupakan refleksi dan aksi iman dan amalsebuah produk pemikiran yang diikuti dengan praksis pembebasan. Ia ditujukan pada kaum mustadh'afin (kaum yang dilemahkan oleh system) termasuk perempuan. Al- Quran dalam hal ini menekankan pada umatnya agar menyantuni anak yatim, menegakkan keadilan, dan menekankan agar kekayaan tidak hanya berputar di segelintir orang. Ini juga dipraktikkan Nabi Muhammad saw, seperti termuat dalam sirah nabawiyyah. Sejarah Nabi, bagi Asghar adalah sejarah perubahan social untuk menentang system yang timpang. Penolakan masyarakat Quraisy bagi Asghar, lebih dikarenakan 
Vol. 2 No. 2 (Desember 2019)

factor ekonomi dari pada factor agama. Mereka yang menentang takut jika hegemoni ekonomi yang ada di genggaman mereka terganggu. Dengan itu, tanpa ragu, Asghar mengatakan bahwa Nabi adalah seorang revolusionertidak hanya dalam pemikiran, tapi juga dalam tindakan. Lewat praksis ia berjuang untuk mengadakan perubahan social pada masanya.(Mun'im, 2011, hlm. 26)

Dan tokoh lainnya yang berusaha membongkar berbagai pengetahuan normatif yang bias kepentingan laki-laki dalam orientasi kehidupan beragama, terutama terkait dengan relasi gender. Tidak ketinggalan, tokoh-tokoh feminis Muslim dari Indonesia juga mulai banyak mengkaji masalah ini dan sudah menghasilkan beberapa buku yang bisa dibaca oleh umat Islam Indonesia. Di antara mereka adalah Nasaruddin Umar, Siti Ruhaini Zuhayatin, Budhy Munawwar Rahman, Cici Farkha, dan masih banyak lagi yang lainnya.(Mun'im, 2011, hlm. 9)

\section{HADITS MISOGINIS}

Kata al- hadits (الحديث)adalah kata mufrad, yang jamaknya al-ahadits ( (الأحاديث) dan dasarnya adalah tahdits (تحديث) artinya "pembicaraan). Dari sisi bahasa, kata hadits memiliki beberapa arti, di antaranya ialah: 1) Al- Jadid (الجديد)artinya "yang lama", dalam arti ini menunjukkan adanya "waktu dekat

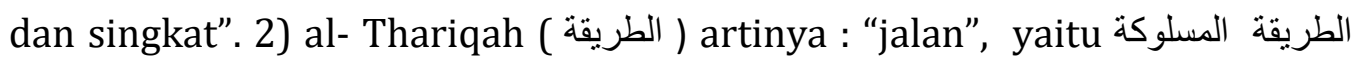

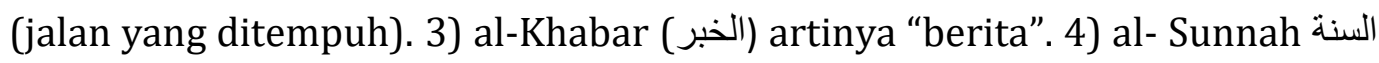
artinya "perjalanan yang memiliki kesamaan arti dengan kata al-Sirah (السيرة). (Zein, 2013, hlm. 1)

Adapun menurut istilah, para ahli memberikan definisi berbeda dengan latar belakang disiplin keilmuan masing-masing. Sesuai dengan latar belakang disiplin keilmuan masing-masing. Sebagaimana perbedaan antara ahli ushul dan ahli hadits, yaitu: menurut ahli hadits:

$$
\text { اقوال النبي صلى الله عليه و سلم و افعاله و احواله }
$$

Artinya: Segala perkataan nabi Muhammad saw, perbuatan dan hal-ihwalnya.

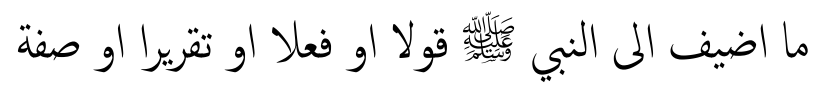

Artinya: Setiap sesuatu yang disandarkan kepada Nabi Muhammad saw, baik berupa perkataan, perbuatan, ketetapan (taqrir) maupun sifat beliau.

Dari definisi tersebut dapat dimengerti bahwa hadits meliputi biografi Nabi Muhammad saw, sifat-sifat yang melekat padanya, baik berupa fisik 
(misalnya masalah tubuh, rambut dan sebagainya) maupun hal-hal yang berkaitan dengan masalah psikis dan kesehariannya, sebelum dan sesudah diangkat menjadi Rasul. Adapun menurut ahli ushul:

$$
\text { اقوال النبي صلى الله عليه و سلم و افعاله و تقريراته التي تثييت الححكام وتقررها }
$$

Artinya: Segala perkataan nabi Muhammad saw, perbuatan dan ketetapannya yang menjadi landasan penetapan hukum.

Dari dua definisi di atas dapat difahami bahwa hadits adalah segala sesuatu yang bersumber dari Nabi Muhammad saw, baik ucapan, perbuatan maupun ketetapan. Akan tetapi keduanya menampakkan perbedaan mendasar dalam membatasi pengertian hadits Nabi Muhammad saw. Jika ahli hadits memandang hadits sebagai sesuatu yang keluar dari manusia sempurna bernama Muhammad, hingga setiap yang melekat padanya, sekalipun berbentuk kebiasaan yang bersifat kemanusiaan, adalah hadits.(Zein, 2013, hlm. 2-3)

Adapun ahli ushul memandang Nabi Muhammad saw sebagai manusia pembuat undang-undang (wetgever) di samping Allah swt. Sehingga hal-hal yang berbentuk kebiasaan dan bersifat kemanusiaan tidak termasuk hadits.(Zein, 2013, hlm. 3)

Selanjutnya adalah sunnah atau السنة adalah kata tunggal, jamaknya adalah as- Sunan (السنن ) artinya:"jalan yang dilalui, terpuji atau tidak", atau berarti "perjalanan". Para ahli berbeda-beda dalam memberikan definisi sunnah menurut istilah. Hal ini lebih disebabkan perbedaan latar belakang, persepsi dan sudut pandang mereka terhadap diri Rasulullah saw. Namun penulis hanya akan mengambil istilah sunnah menurut ahli hadits.

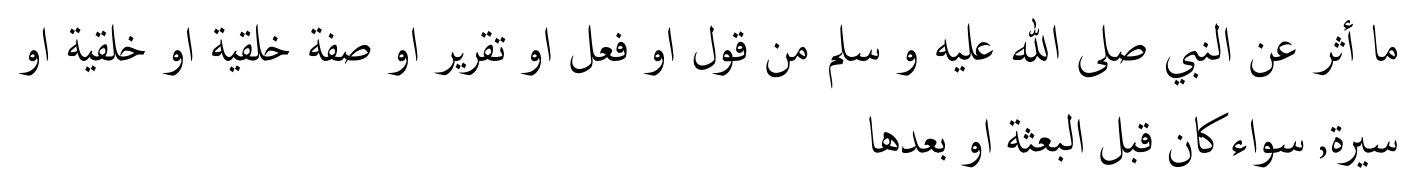

Artinya: Segala sesuatu yang bersumber dari Nabi Muhammad saw, baik berupa perkataan, perbuatan, ketetapan (taqrir), perangai, budi pekerti, maupun perjalanan hidup, baik sebelum diangkat sebagai Rasul maupun sesudahnya.

Dari definisi di atas nampaknya para ahli hadits membawa masuk semua bentuk kebiasaan nabi Muhammad saw ( baik yang melahirkan syara' 
Vol. 2 No. 2 (Desember 2019)

maupun tidak) ke dalam pengertian sunnah. Dengan sendirimya mereka pun memaknai sunnah sama dengan hadits.

Selain hadits dan sunnah ada istilah-istilah lain yang berkaitan dengan hadits, tidak hanya bagi kalangan awam istilah-isilah ini sering dimaknai sama, bahkan kebanyakan para muhadditsin, baik yang termasuk aliran modern maupun kuno (salaf) berpendapat bahwa istilah-istilah ini murodif atau sinonim.(Fathurrahman, 1974, hlm. 28) Padahal jika ditelisik lebih mendalam ada perbedaan-perbedaan diantaranya. Walaupun ada beberapa ulama yang membedakan antara istilah hadits, sunnah, atsar dan khabar yang perbedaan itu tidaklah terlalu prinsipil. Umpamanya ada sebuah pendapat yang membedakan bahwa pengertian hadits itu hanya terbatas pada apa yang datang dari Nabi Muhammad saw saja, sedang al khabar terbatas kepada apa yang datang dari selainnya. Karena itu orang yang tekun kepada ilmu hadits saja disebut muhaddis, sedang orang yang tekun kepada khabar disebut akhbary. Ada pula pendapat yang membedakannya dari segi umum dan khusus muthlaq, yakni tiap-tiap hadits itu khabar, tetapi sebaliknya bahwa tidak tiap-tiap khabar itu dapat dikatakan hadits. Di samping ada pendapat yang mengatakan, bahwa atsar itu ialah yang datang dari sahabat, tabi'in dan orang-orang sesudahnya, juga ada pendapat yang mengatakan, bahwa istilah atsar itu adalah lebih umum penggunaannya daripada istilah hadits dan khabar, karena istilah atsar itu mencakup segala berita dan perilaku para sahabat, tabi'in dan selainnya.(Fathurrahman, 1974, hlm. 28)

Terlepas dari perbedaan istilah, dalam memahami hadits adakalanya perlu didampingi oleh disiplin ilmunya sendiri yaitu 'ulumul hadits. Dalam 'ulumul hadits ada beberapa bab atau sub bab sebagai alat untuk memahami hadits secara komprehensif. Memaknai hadits tidak sekedar tekstualis tapi dengan mencari makna substansif dalam hadits tersebut. Hal ini bertujuan agar menggunakan teks-teks hadits tidak salah kaprah, dan salah faham. Seperti halnya dalam memaknai hadits-hadits yang didalamnya terkandung 'perempuan'.

Hadits-hadits yang menyinggung soal perempuan tidak sedikit yang bernada misoginis atau mengandung unsur kebencian, merendahkan pada perempuan. Ini perlu dianalisis dengan mengurai kembali siapa yang meriwayatkan hadits- hadits tersebut, ada kepentingan apa dibalik hadits tersebut. Bisa saja periwayat terpengaruh pada konstruksi sosial budaya patriarki. Hadits-hadits tersebut bisa dikritisi.

Istilah hadits dalam kritik hadits berbeda dengan istilah sunnah. Hadits difahami sebagai formalisasi dari sunnah. Dikatakan sebagai 
Vol. 2 No. 2 (Desember 2019)

formalisasi sunnah, karena hadits merupakan catatan secara formal dari konsep perilaku nabi Muhammad saw yang diwarisi dari generasi sahabat ke generasi setelahnya. Adapun istilah sunnah adalah konsep perilaku nabi Muhammad saw yang aplikatif. Dengan demikian, hadits dan kritik hadits merupakan bagian dai proses sosiologis yang dikonstruksi berdasarkan gagasan manusia.(Fathurrahman, 1974, hlm. 9)

Hadits sebagai catatan historis tentang Rasulullah lebih mudah dimasuki kepentingan-kepentingan politis, baik pada wilayah penafsiran maupun metodologi. Gerakan feminisme mensinyalir adanya penetrasi budaya patriarkal dalam formalisasi sunnah sehingga pada zaman ini-setelah sekian waktu berjarak dengan proses transmisi hadits - diketemukan haditshadits yang menyudutkan kedudukan perempuan dalam berbagai segi kehidupan. Kaum feminis memahami hadits- hadits ini dengan nama haditshadits misogini.(Kadarusman, 2005, hlm. 69)

Secara historis, semangat untuk menghapus patrimonialisme terkait perbedaan gender,sekaligus memberikan ruang kepada perempuan sudah ada di zaman Nabi. Larangan-larangan untuk melakukan kekerasan, penindasan dan diskriminasi terhadap perempuan sendiri mulai ditegaskan dalam beberapa ayat al-Qur'an. Sebagai bukti adalah adanya larangan seorang anak mewarisi ibunya sendiri dari bapaknya dan perempuan mulai diberi hak warisan dari keluarganya yang meninggal. Namun, pasca wafatnya Rasulullah, wilayah Islam mulai meluas ke berbagai daerah yang kebetulan masih memiliki tradisi memarginalkan dan mengkirikan perempuan, sehingga tak terelakkan terjadinya akulturasi dan asimilasi kebudayaan yang kurang menguntungkan dan mulai membayang-bayangi semangat yang diperjuangkan Islam era Nabi. Sebagai imbasnya, pasca ekspansi ke wilayahwilayah persebaran Islam, tak terelakkan lagi adanya pemahaman terhadap teks-teks agama yang bias gender terhadap perempuan. Teks teks tersebut dianggap sudah segala-galanya dan harus dipatuhi. Konstruk pemahaman seperti ini justru dicengkram kuat oleh Ulama' saat itu hingga mampu menghegemoni dan meracuni nalar masyarakat. Masyarakat pun tanpa daya untuk mengkritisinya. Pemahaman sudah berubah menjadi "mitos" agama yang tak boleh disentuh. Untuk itu, teks-teks agama menjadi penting untuk dikaji ulang, dalam hal ini teks hadits yang dinilai misoginis2 dan menyudutkan perempuan. Hadits tersebut perlu dikritisi untuk mengungkap nilai yang sebenarnya dikandung. Memang kajian ini memiliki kesamaan dengan apa yang disuarakan pegiat feminis. Apakah benar Islam begitu kejam memperlakukan perempuan yang sama-sama makhluk Allah? Sedangkan Allah menciptakan perempuan sebagai patner (zaujah) bagi laki- 
laki. Apalagi mengingat adanya klaim bahwa mayoritas penghuni neraka adalah perempuan, padahal fakta sekarang banyak perempuan yang lebih sholehah dari pada laki-laki. Apakah hanya karena alasan sering membangkang pada suami mereka masuk neraka? padahal suami mereka jarang bahkan tidak pernah memberikan hak pada istrinya. Dan semua itu tertulis dalam beberapa kitab kumpulan hadits dengan predikat shahịh, terutama dalam Shahịh al-Bukhārī.(Muqtada, 2014, hlm. 87-88)

Hadits-hadits misogini sebagai cerminan perkataan, perbuatan dan keputusan-keputusan Rasulullah sangat kontradiktif dengan sejarah peran perempuan pada masa Rasulullah dan periwayatan sunnah. Pada masa perjuangan Nabi, perempuan memiliki peran yang strategis, dari penyejuk hati Nabi (istri-istri Nabi) sampai yang bertugas di medan perang. Dengan demikian deksriminasi terhadap perempuan dalam matan hadits bukan hanya saja menyalahi dimensi kemanusiaan perempuan, tetapi merupakan bentuk reduksi terhadap ajaran dan citra kenabian. Kegelisaha teologisfilosofis ini sangat dirasakan aktivis gerakan teologi feminism. Kegelisahan ini pula yang mendorong mereka mengajukan kritik epistemologis terhadap formalisasi hadits dan proses pemaknaan hadits.(Muqtada, 2014, hlm. 88)

Untuk memahami persoalan ini, terdapat tiga formulasi pembacaan kaum feminis terhadap hadits. Pertama, ada pembawa hadits pada salah satu atau lebih level sanad yang menggunakan hadits secara politis untuk mendukung tegaknya tradisi patriarkal. Akibatnya hadits-hadits gender dibelokkan menjadi hadits yang secara matan yang bersifat misogini. Kedua, metodologi kritik hadits yang lebih berorientasi untuk mengungkap keshahihan sanad pada matan serta berpihak pada truth claim yang berakibat adanya suatu generasi tertentu yang dipandang tanpa cacat dalam meriwayatkan hadits. Hal ini menyebabkan diterimanya beberapa hadits misogini dengan pertimbangan sanad semata, padahal terdapat cacat pada matan, dan berarti terdapat kejanggalan dalam proses periwayatan hadits tersebut. Ketiga, pemahaman matan hadits yang dilakukan secara doktrinalnormatif tanpa melihat proses hermeneutis yang terjadi seputar pembentukan teks (penyingkapan pesan moral teks). Akibatnya haditshadits misogini difahami secara parsial dan patriarkal, sementara substansi pesan teks tidak dapat ditangkap.

Contoh hadits - hadits yang diklaim misoginis salah satunya ada dalam kitab shahih bukhari yang diklasifikasikan dalam enam bagian: 1) perempuan adalah mayoritas penghuni neraka karena dua alas an: tidak pandai mensyukuri nikmat dan makhluk yang kurang akalnya, 2) perempuan sebagai penyebab batalnya shalat, 3) perempuan makhluk pembawa sial 4) 
Vol. 2 No. 2 (Desember 2019)

penciptaan perempuan dari tulang rusuk yang bengkok, 5) perempuan tidak layak menjadi pemimpin dan 6) perempuan sebagai pelayan suami mereka.(Muqtada, 2014, hlm. 90-91)

Mengutip Dr. M. Rikza, Di bawah ini diklasifikasikan hadits misoginis yang tercantum dalam kitab shahih bukhari.

\begin{tabular}{|c|c|c|c|}
\hline No. & $\mathrm{Bab}$ & Sub-bab & Tema \\
\hline 1 & Al-Nikah & $\begin{array}{l}\text { Idza Batat Al-Mar'at } \\
\text { Muhajirat Firaasy Zaujiha. }\end{array}$ & $\begin{array}{l}\text { Hukuman Bagi Istri } \\
\text { Yang Menolak } \\
\text { Bersetubuh Dengan } \\
\text { Suami }\end{array}$ \\
\hline 2 & Al-Nikah & $\begin{array}{l}\text { Shaum Al-Mar'at Bi Idzni } \\
\text { Zaujiha Tathawu'an } \\
\text { (Puasanya Istri Atas } \\
\text { Seizin Suaminya) }\end{array}$ & $\begin{array}{l}\text { Larangan Bagi Istri } \\
\text { Tanpa Seizin Suaminya. }\end{array}$ \\
\hline 3 & Al-Nikah & $\begin{array}{l}\text { Al-Midarah Ma'a Al-Nisa } \\
\text { (Bersikap Lembut Kepada } \\
\text { Perempuan) }\end{array}$ & $\begin{array}{l}\text { Perumpamaan } \\
\text { Perempuan Seperti } \\
\text { Tulang Rusuk. }\end{array}$ \\
\hline 4 & Al-Nikah & $\begin{array}{l}\text { Al-Washah Bi Al-Nisa' } \\
\text { (Berwasiat Untuk } \\
\text { Perempuan) }\end{array}$ & Penciptaan Perempuan \\
\hline 5 & Al-Nikah & $\begin{array}{l}\text { Ma Yattaqu Min Syu'umi } \\
\text { Al-Mar'at (Seseorang } \\
\text { Yang Takut Atas Bahaya } \\
\text { Perempuan) }\end{array}$ & $\begin{array}{l}\text { Mayoritas Penghuni } \\
\text { Neraka Adalah } \\
\text { Perempuan. }\end{array}$ \\
\hline 6 & Al-Haidh & $\begin{array}{l}\text { Tarku Al-Haidh Al-Shaim } \\
\text { (Meninggalkan } \\
\text { Perempuan Yang Kotor) }\end{array}$ & $\begin{array}{l}\text { Mayoritas Penghuni } \\
\text { Neraka Adalah } \\
\text { Perempuan }\end{array}$ \\
\hline 7 & $\begin{array}{l}\text { Al-Mukhtashar } \\
\text { (al jihad) }\end{array}$ & $\begin{array}{l}\text { Ma Yudzkaru Min Syu'um } \\
\text { Al-Farasy (Apa Yang } \\
\text { Disebut Sebagai Kesialan } \\
\text { Kuda). }\end{array}$ & $\begin{array}{l}\text { Perempuan Salah Satu } \\
\text { Pembawa Sial }\end{array}$ \\
\hline 8 & Al-Shalat & $\begin{array}{l}\text { Man Qaaala La Yuqtha'u } \\
\text { Al-Shalat Syai'un (Orang } \\
\text { Berkata Bahwa Tidak Ada } \\
\text { Sesuatu Yang } \\
\text { Memutuskan Shalat) }\end{array}$ & $\begin{array}{l}\text { Perempuan Dapat } \\
\text { Membatalkan Shalat }\end{array}$ \\
\hline
\end{tabular}




\begin{tabular}{|l|l|l|l|}
\hline 9 & Al-Nikah & $\begin{array}{l}\text { Ma Yattaqi Min Syu'um Al- } \\
\text { Mar'at (Seseorang Yang } \\
\text { Takut Atas Bahaya } \\
\text { Perempuan). }\end{array}$ & $\begin{array}{l}\text { Perempuan Adalah } \\
\text { Fitnah Bagi Laki-Laki }\end{array}$ \\
\hline
\end{tabular}

Dari beberapa hadits misoginis di atas penulis mencoba menganalisis bagaimana sebenarnya substansi dari hadits pertama dari table di atas, yaitu hadits yang menyatakan bahwa perempuan akan dilaknat oleh malaikat sampai subuh ketika menolak ajakan bersenggama dari suami.

Adapun hadits tersebut berbunyi:

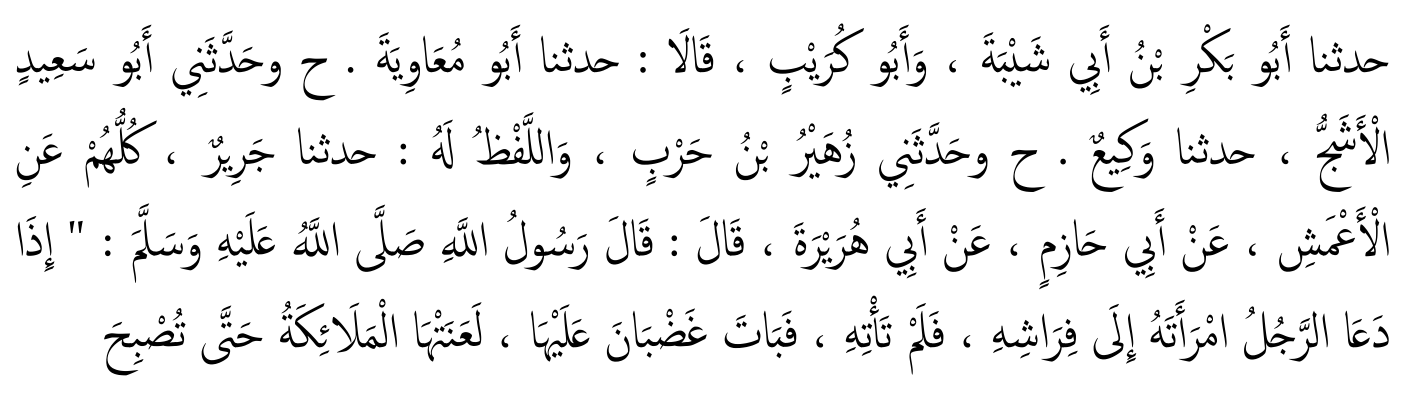

Ibnu Hajar al-Asqalani menjelaskan إذ دعا الرجل امر أته إلى فراثه (apabila seorang laki-laki memanggil istrinya ke tempat tidurnya). Menurut Ibnu Abu Jamrah, secara zhahir "tempat tidur di sini merupakan kiasan perbuatan jima'. Hal ini didukung oleh sabdanya, إذ دعا الرجل امرأته إلى فراشه (anak untuk pemilik tempat tidur (suami yang sah)), yakni untuk mereka yang melakukan hubungan intim di tempat tidur. Penggunaan kata kiasan terhadap hal-hal yang tabu disebutkan sangat banyak dalam al-quran dan sunnah. Dia berkata pula, "makna zahir hadits adalah pengkhususan laknat kepada mereka yang melakukan itu semalaman berdasarkan perkataannya "hingga subuh". Seakan-akan rahasianya adalah penekanan bagi hal itu pada waktu malam dan kuatnya dorongan kepadanya. Namun, istri boleh menolak di siang hari. Hanya saja malam disebutkan secara khusus, karena ia merupakan waktu di mana banyak terjadi perbuatan tersebut.(Usamah, 2013, hlm. 146)

Menurut feminis muslim Indonesia yaitu, K.H. Husien Muhammad, hadits tentang laknat malaikat ini tidak hanya terdapat pada satu riwayat, namun hadits-hadits ini tidak dapat difahami dengan hanya melihat pada teks hadits atau dengan pemahaman apa adanya, karena hadits ini ditujukan pada perempuan yang tidak mempunyai alasan yang kuat untuk menolak ajakan suaminya, namun jika ada alasan atau takut akan didzalimi suaminya maka perbuatan itu dapat dibenarkan. Hadits tentang wanita yang enggan melayani suaminya ini menurut Zaitunah tidak dapat disimpulkan begitu 
Vol. 2 No. 2 (Desember 2019)

saja, sebab apabila suami mengajak istri untuk melayani keinginannya, sedangkan istri dalam keadaan tidak memungkinkan (kerena lelah atan lainnya) dan suami tetap memaksa, pada hakikatnya suami tersebut melanggar prinsip mu'asyarah bil ma'ruf tersebut. Justru seharusnya suami melindungi istri dalam keadaan lelah atau tidak enak badan. Masdar F. Mas'udi menerangkan bahwa Rasulullah saw datang sebagai rahmat bagi seluruh alam, maka tidak mungkin beliau memberi senjata untuk ketidakadilan, lebih-lebih ketidakadilan oleh suami terhadap istri. Ini bertentangan sendiri dengan sabda beliau sendiri yang menekankandengan sangat agar suami memperlakukan istri dengan baik, bijak dan ma'ruf, Inilah makanya arti laknat itu tidak dapat diartikan secara harfiah. Al-Shan'ani mengartikan laknat itu sebagai suasana tegang di dalam rumah tangga, akibat penolakan hubungan seks oleh salah satu pihak.(Usamah, 2013, hlm. 147)

Siti Musdah Mulia mengatakan kata yang perlu dianalisis dari hadits ini adalah kata abat (penolakan istri). Dari konteks ini perlu diketahui alasanalasan, atas dasar apa penolakan itu dilakukan dan apa latar belakangnya. Penolakan istri terhadap ajakan suaminya untuk berhubungan intim tanpa didasari alasan yang logis atau bahkan tidak beralasan, tentu pantas memperoleh hukuman berupa kutukan dari malaikat. Dan dalam keadaan demikian dia dipandang nusyuz Akan tetapi, jika penolakan itu atas dasar kemanusiaan, seperti sakit, lelah, capek atau sedang tidak bergairah. Hal itu tentu dapat dibenarkan. Atau penolakan istri itu disebabkan oleh kondisi suami yang selama ini memperlakukannya secara bengis dan tidak manusiawi, maka kesalahan ada pada pihak suami dan dia pun mesti dipandang nusyuz dan juga mendapat kutukan para malaikat.(Usamah, 2013, hlm. 147)

Dari pemaparan para aktifis tadi, hadits tersebut tidak dapat dimaknai secara harfiah saja. Jika demikian, perempuan seolah-olah menjadi pemuas seksual laki-laki belaka. Padahal perempuan juga memiliki beberapa hak salah satunya hak reproduksi perempuan. Di antaranya: pertama, hak jaminan keselamatan dan kesehatan. Hak tersebut mutlak ada, mengingat resiko yang sangat besar yang dialami oleh ibu, dalam menjalankan fungsi reproduksinya bagi ibu dan anak. Kedua, hak jaminan kesejahteraan, bukan hanya pada saat proses vital reproduksi (mengandung, melahirkan, dan menyusui) berlangsung, tetapi di luar masa-masa itu dalam statusnya sebagai ibu dari anak-anak. Ketiga hak ikut mengambil keputusan yang berhubungan dengan kepentingan perempuan (istri) terutama yang menyangkut fungsi reproduksi. Hal ini tercermin dalam prinsip dasar ajaran Islam dan mengambil keputusan harus senantiasa melibatkan hak-hak yang 
Vol. 2 No. 2 (Desember 2019)

berkepentingan.(Abdullah, 2016, hlm. 21) sebagaimana dalam QS. Al- Syura: 38.

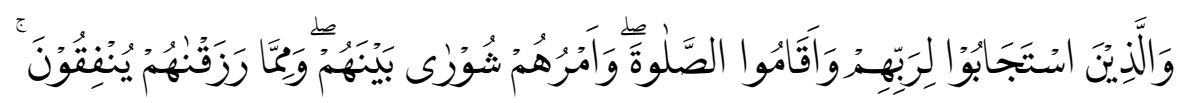

Artinya: dan (bagi) orang-orang yang menerima (mematuhi) seruan Tuhannya dan mendirikan shalat, sedang urusan mereka (diputuskan) dengan musyawarat antara mereka; dan mereka menafkahkan sebagian rezeki yang Kami berikan kepada mereka. (Q.S Al-Syura: 38).

Hak reproduksi perempuan dalam Islam dimulai dari pembahsan memasuki kehidupan rumah tangga yang mencakup empat hal penting, yaitu: hak memilih pasangan, hak menikmati hubungan seksual, hak menentukan kehamilan dan hak merawat dan mengasuh anak.(Abdullah, 2016, hlm. 21) Prinsip-prinsip tersebut harus menjadi dasar dalam setiap perjanjian antara dua belah pihak. Perjanjian yang dilakukan tanpa merealisasikan prinsipprinsip di atas tadi akan menimbulkan ketimpangan dan ketidakadilan. Dalam al- Quran dijelaskan:

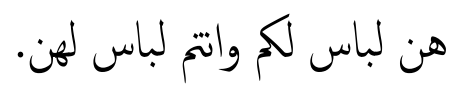

Artinya: Mereka, para istri adalah pakaian kalian, para suami dan sebaliknya para suami juga merupakan pakaian bagi para istri. (QS al- Baqarah, 187)

Ayat ini secara tegas menghimbau agar perkawinan dibangun atas dasar prinsip-prinsip kesetaraan, sekaligus juga menunjukkan ide dasar Islam tentang relasi seksual. Dengan ungkapan lain, hak yang dimiliki perempuan dalam menyalurkan naluri seksualnya adalah setara dengan dengan hak laki-laki atasnya. Ini berarti pula bahwa relasi seksual harus dilakukan berdasarkan atas asas kesamaan atau asas kesetaraan, hak suami untuk relasi seksual menjadi kewajiban istri, dan demikian pula sebaliknya, dengan begitu tidak ada lagi praktek dominasi atau kekuasaan mutlak dalam kehidupan keluarga.(Abdullah, 2016, hlm. 21)

\section{PENUTUP}

'Gender' dapat dimaknai sebagai 'perbedaan yang tampak antara laki-laki dan perempuan dilihat dari segi nilai dan tingkah laku'. Secara terminologis, gender bisa didefinisikan sebagai harapan-harapan budaya terhadap laki-laki dan perempuan. Gender dipandang sebagai suatu konsep kultural yang dipakai untuk membedakan peran, perilaku, mentalis, dan 
Vol. 2 No. 2 (Desember 2019)

karakteristik emosional antara laki-laki dan perempuan yang berkembang dalam masyarakat. Difahami bahwa gender merupakan suatu sifat yang dijadikan dasar untuk mengidentifikasi perbedaan antara laki-laki dan perempuan dilihat dari segi kondisi sosial dan budaya, nilai dan perilaku, mentalitas, dan emosi, serta factor-faktor nonbiologis lainnya. Adanya ketimpangan dalam gender membangkitkan kaum feminis untuk menuntut hak mereka yang ditutupi sekian lamanya. Pembahasan tentang bagaimana feminisme lahir dimulai dengan pemaparan tentang bagaimana masyarakat memandang tentang peempuan, hingga munculnya kesadaran diri dari sekelompok orang (yang berperan sebagai agent of change) terhadap adanya ketidakadilan (tidak egaliter) terhadap perempuan di dalam cara pandang masyarakat tersebut. Adanya perlakuan yang tidak manusiawi terhadap perempuan atau maraknya kebencian terhadap wanita memunculkan istilah baru, misoginis.

Hadits-hadits yang menyinggung soal perempuan tidak sedikit yang bernada misoginis atau mengandung unsur kebencian, merendahkan pada perempuan. Ini perlu dianalisis dengan mengurai kembali siapa yang meriwayatkan hadits- hadits tersebut, ada kepentingan apa dibalik hadits tersebut. Bisa saja periwayat terpengaruh pada konstruksi sosial budaya patriarki. Hadits-hadits tersebut bisa dikritisi. Hadits-hadits misogini sebagai cerminan perkataan, perbuatan dan keputusan-keputusan Rasulullah sangat kontradiktif dengan sejarah peran perempuan pada masa Rasulullah dan periwayatan sunnah. Pada masa perjuangan Nabi, perempuan memiliki peran yang strategis, dari penyejuk hati Nabi (istri-istri Nabi) sampai yang bertugas di medan perang. Dengan demikian deksriminasi terhadap perempuan dalam matan hadits bukan hanya saja menyalahi dimensi kemanusiaan perempuan, tetapi merupakan bentuk reduksi terhadap ajaran dan citra kenabian. Kegelisaha teologis-filosofis ini sangat dirasakan aktivis gerakan teologi feminism. Kegelisahan ini pula yang mendorong mereka mengajukan kritik epistemologis terhadap formalisasi hadits dan proses pemaknaan hadits.

Salah satu hadits misoginis yaitu, bagaiamana hukuman perempuan yang menolak ajakan suami untuk bersenggama. Ini dirasa mengunggulkan satu pihak yaitu suami. Seolah-olah otoritas dalam seks ada di tangan suami. Padahal jika menurut Hak reproduksi perempuan dalam Islam, ada hak istri dalam hal itu. Hak tersebut dimulai dari pembahsan memasuki kehidupan rumah tangga yang mencakup empat hal penting, yaitu: hak memilih pasangan, hak menikmati hubungan seksual, hak menentukan kehamilan dan hak merawat dan mengasuh anak. Prinsip-prinsip tersebut harus menjadi 
dasar dalam setiap perjanjian antara dua belah pihak. Perjanjian yang dilakukan tanpa merealisasikan prinsip-prinsip di atas tadi akan menimbulkan ketimpangan dan ketidakadilan.

Menaggapi hal ini, terdapat tiga formulasi pembacaan kaum feminis terhadap hadits misogini. Pertama, ada pembawa hadits pada salah satu atau lebih level sanad yang menggunakan hadits secara politis untuk mendukung tegaknya tradisi patriarkal. Kedua, metodologi kritik hadits yang lebih berorientasi untuk mengungkap keshahihan sanad pada matan serta berpihak pada truth claim yang berakibat adanya suatu generasi tertentu yang dipandang tanpa cacat dalam meriwayatkan hadits. Ketiga, pemahaman matan hadits yang dilakukan secara doktrinal-normatif tanpa melihat proses hermeneutis yang terjadi seputar pembentukan teks (penyingkapan pesan moral teks).

\section{REFERENSI}

Abdullah, U. (2016). Hak- Hak Perempuan Dalam Keluarga Menurut Pandangan Asma Barlas. UIN Syarif Hidayatullah, Jakarta.

Ainiyah, Q. (2015). Keadilan Gender Dalam Islam. Malang: Kelompok Intrans Publishing.

Ara, F., \& Ananda. (2004). Wanita Dalam Konsep Islam Modernis. Jakarta: Pustaka Firdaus.

Bhasin, K., \& Nighat, S. K. (1994). Persoalan-Persoalan Pokok Mengenai Feminisme dan Relevansinya. Jakarta: Gramedia dan Yayasan Kalyanamitra.

el Saadawi, N. (2001). Perempuan dalam Budaya Patriarki. Yogyakarta: Pustaka Pelajar.

Fathurrahman. (1974). Ikhtisar Musthalahul Hadis. Bandung: PT Al- ma'arif.

Kadarusman. (2005). Agama, Relasi Gender dan Feminisme. Yogyakarta: Kreasi Wacana.

Kulsum, U. (2017). Nawal El-Saadawi:Membongkar Budaya Patriarkhi Melalui Sastra. 3, 1.

Lufaefi. (2017). Telaah Penafsiran Ayat-Ayat Kekerasan: Upaya Mewujudkan Perdamaian dalam Bingkai Keindonesiaan. REFLEKSI, Volume 16, 1.

Muhtador, M. (2017). Gagasan Riffat Hasan tentang Kritik Gender atas Hadis Misoginis. Jurnal Millati, 2, 2.

Mun'im, A. R. Z. (2011). Epistemologi Feminis Asghar Ali Engineer. Jurnal al' adalah, 14, 1.

Muqtada, R. (2014). Kritik Nalar Hadis Misoginis. Jurnal Musawa, 13, 2. 


\section{AT-TIBYAN}

Journal Of Qur'an and Hadis Studies

Vol. 2 No. 2 (Desember 2019)

Muslikhati, S. (2001). Feminisme dan Pemberdayaan Perempuan dalam Timbangan Islam. Jakarta: Gema Insani.

Rokhmansyah, A. (2016). Pengantar Gender dan Feminisme: Pemahaman Awal Kritik Sastra Feminisme. Yogyakarta: Garudhawaca.

Rufikasari. (2014). Hadis-Hadis Misogynist Dalam Riwayat Tirmidzi (Studi

Komparatif Antara pemikiran Feminis Dan Muhaddisin). Universitas Islam Negeri Sultan Syarif Kasim, Riau.

Umar, N. (1999). Argumen Kesetaraan Jender Perspektif Al-Qur'an. Jakarta: Paramadina.

Usamah. (2013). Pemahaman Hadis-Hadis Misoginis Menurut Ulama Hadis Dan Feminis Muslim Indonesia. Jurnal Studia Insania, 1, 2.

Zein, M. M. (2013). Ilmu Memahami Hadist Nabi: Cara Praktis Menguasai Ulumul Hadis Dan Mustholah Hadits. Yogyakarta: Pustaka Pesantren. 